\title{
Analysis of Spatio-Temporal Dynamics of Land Use in the Bouba Ndjidda National Park and Its Adjacent Zone (North Cameroun)
}

\author{
José Elvire Boukeng Djiongo,,2, André Desrochers', Marie Louise Tiencheu Avana3, \\ Damase Khasa ${ }^{1}$, Louis Zapfack ${ }^{4}$, Éric Fotsing 5 \\ ${ }^{1}$ Department of Wood and Forest Sciences, Faculty of Forestry, Geography and Geomatics, Laval University, Quebec, Canada \\ ${ }^{2}$ Garoua Wildlife School, Garoua, Cameroun \\ ${ }^{3}$ Department of Forestry, Faculty of Agronomy and Agricultural Sciences, University of Dschang, Dschang, Cameroon \\ ${ }^{4}$ Department of Plant Biology, Faculty of Sciences, University of Yaoundé 1, Yaoundé, Cameroon \\ ${ }^{5}$ Department of Computer Engineering, University Institute of Technology Fotso Victor University of Dschang, Bandjoun, \\ Cameroon \\ Email: elvirejose@yahoo.fr
}

How to cite this paper: Djiongo, J. E. B., Desrochers, A., Avana, M. L. T., Khasa, D., Zapfack, L., \& Fotsing, É. (2020). Analysis of Spatio-Temporal Dynamics of Land Use in the Bouba Ndjidda National Park and Its Adjacent Zone (North Cameroun). Open Journal of Forestry, 10, 39-57. https://doi.org/10.4236/ojf.2020.101004

Received: October 19, 2019

Accepted: December 10, 2019

Published: December 13, 2019

Copyright $\odot 2020$ by author(s) and Scientific Research Publishing Inc. This work is licensed under the Creative Commons Attribution International License (CC BY 4.0).

http://creativecommons.org/licenses/by/4.0/ (c) (i) Open Access

\begin{abstract}
We evaluated the dynamics of land use in the Bouba Ndjidda National Park (BNNP) and adjacent areas, in northern Cameroon. Using a maximum likelihood supervised classification of satellite images from 1990 to 2016, coupled with field and a socio-economic survey, we performed a robust land-use classification. Between 1990 and 2016, the area included eight classes of land use, with the largest in 1990 being the woody savannah (42.9\%) followed by the gallery forest (20.2\%) and the clear forest (16.3\%). Between 1990 and 1999, the gallery forest lost $64.8 \%$ of its area mostly to the benefit of woody savannahs. Between 1999 and 2016, the largest loss of area was that of the clear forest, which decreased generally by $43.2 \%$ in favor of woody savannah. Rates of increase of crop field areas were $59.6 \%$ and $78.8 \%$ respectively for the periods of 1990 to 1999 and 1999 to 2016 to the detriment of woody savannahs. We attribute the changes in land use observed mainly to the increasing human population and associated agriculture, overgrazing, fuelwood harvesting and bush fires. The exploitation of non-timber forest products and climatic factors may also have changed the vegetation cover. We recommend the implementation of farming techniques with low impact on the environment such as agroforestry.
\end{abstract}

\section{Keywords}

Remote Sensing, Spatio-Temporal Dynamics, Bouba Ndjidda National Park, Vegetation Cover, Land Use 


\section{Introduction}

Protected Areas (PAs) are an important component of biodiversity conservation in most countries (Tardif \& Sarrasin, 2014). They are central to protect endangered species and are also viewed as significant providers of ecosystem services and biological resources (Dudley, 2008). Yet, Central African PAs are undergoing degradation (Doumenge et al., 2015). Clearing of land for agriculture and logging for urban markets, increase pressure on PAs. Economic activities such as agriculture, animal husbandry, hunting, timber harvesting and conservation efforts through protected areas are usually made without land use planning in most African regions (Arouna et al., 2009). One of the consequences of these practices is the degradation of vegetation cover both inside and adjacent to Protected Areas.

The Bouba Ndjidda National Park (BNNP or "park") is part of the network of protected areas of northern Cameroon. Of the three national parks in this network, it is the richest and most diversified in wildlife species (Omondi et al., 2008). It constitutes the Bouba Ndjidda Technical Operational Unit (TOU) with the hunting zones (ZIC) that surround it. Due to poaching, this protected area lost about 200 elephants in 2012 (Scholte, 2012). For about two decades, the growth of human population in this area has also favored the collection of wood and the extension of agricultural areas (Nature Information Tracks, 2017). However, these pressures remain less quantified at the spatial and temporal scales, limiting the development of strategies adapted to the context. Given the multifaceted pressure on the vegetative cover of the BNNP and adjacent areas, it is relevant to study the different states of the plant formations, and their tendency, and to infer the driving factors of these changes.

The availability of satellite images from Landsat TM, ETM+ and OLI-TIRS sensors, which have been used earlier for the analysis of vegetation cover in Protected Areas in tropical zones, provides an opportunity to characterize and monitor changes in vegetation cover in and around these PAs.

The purpose of this study is to understand the spatial and temporal changes of the vegetation cover in order to guide the decision making regarding the land use of this area. More specifically, the study aims to make a spatio-temporal analysis of land use in the BNNP and its periphery between 1990 and 2016, and to determine the factors driving those changes.

\section{Material and Methods}

\subsection{Characteristics of the Study Area}

The BNNP is located in the Soudano-Sahelian zone of Cameroon, east of the network of Protected Areas of the Northern Region. Created in 1947, the BNNP extends between $08^{\circ} 21^{\prime} \mathrm{N}-09^{\circ} 00^{\prime} \mathrm{N}$, and $14^{\circ} 25^{\prime} \mathrm{E}-14^{\circ} 55^{\prime} \mathrm{E}$. Its surface area is about 700,000 ha including the hunting zones $(10,11,12,17,20,21,23)$ that surround it (Figure 1). The climate is Sudano-Sahelian as described by Gonné (2016). The locality of Bouba Ndjidda receives between 800 and $1250 \mathrm{~mm}$ of 

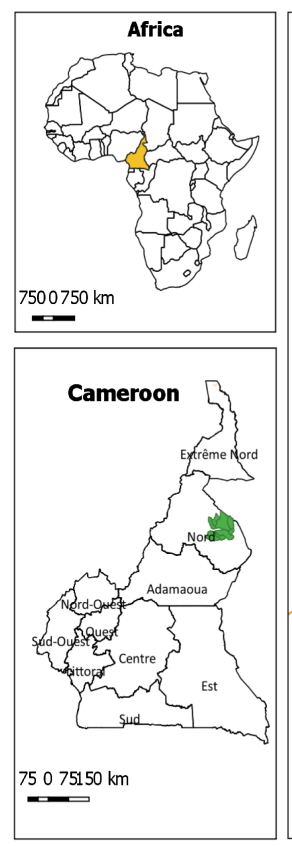

Source: Ecole de Faune de Garoua, 2016; Open Street Map 2017

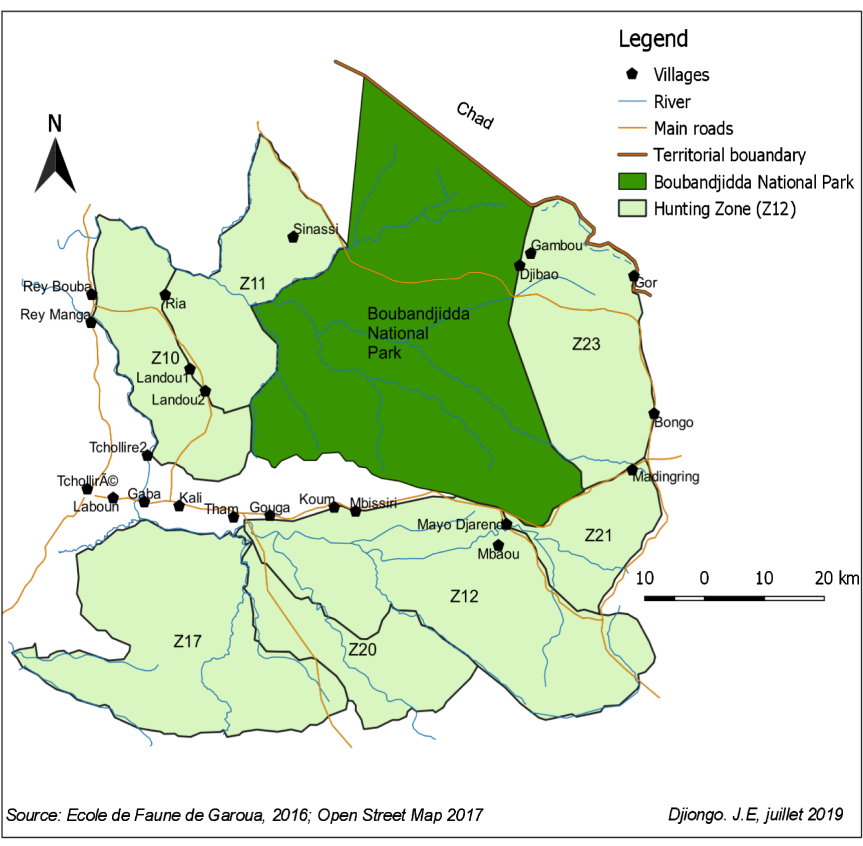

Djiongo. J.E, juillet 2019

Figure 1. Location of Bouba Ndjidda National Park and its adjacent zone.

precipitation per year, the rainiest months being August and September. The average annual temperature is $28^{\circ} \mathrm{C}$. Soils are generally ferruginous leached tropical or a combination of ferruginous and hydromorphic soils (Brabant, 1972). According to Nature Information Tracks (2017), the vegetation within the Bouba Ndjida National Park is composed of characteristic species of the Soudanian zone found in woody savannahs, gallery forests and dry clear forests. Around the BNNP, there are shrubby savannahs, crop fields and forest fallows (Ministry of Forest and Wildlife, 2010b). Twenty-eight villages are adjacent to the east, south and west limits of the park and belonging to the district of Tcholliré, Madingring and Rey Bouba. The population of these districts is characterized by a great diversity of ethnic groups (autochthonous and semi-migrant groups) totalling 27,500 inhabitants in 1987 (RGPH, 1987). It rose to 194,065 in 2005 (RGPH, 2005) and was estimated at 260,149 in 2016 (RGPH, 2010b). Agriculture and livestock rearing are the main activities practiced extensively; the main crops being cotton (the only cash crop), maize, groundnuts and sorghum (Djiongo, 2015; Ministry of Forest and Wildlife, 2010b).

\subsection{Map Data and Digital Processing of Satellite Images}

We classified land use from Landsat 4 - 5 (TM) images of November 24, 1990, Landsat 7 (ETM+) of November 17, 1999 and Landsat 8 (OLI/TIRS) of November 23, 2016. This identification of successive vegetation states over a period of twenty-six years allows a better appreciation in the states of change of plant formations. Several reasons justify the choice of this period: 1) It was in the early 1990s that rural forestry emerged for foresters (Montagne \& Dubus, 1992) by which "rural people must become the managers of their entire land, including 
woodlands, based on the notion of a multipurpose tree". Priority is thus given to rural forestry, which is perfectly integrated with other peasant activities such as livestock and agricultural production (Goudet, 1992). 2) This period also includes the year 1994, from which the new Cameroonian forestry law provides a framework for the management of natural formations by offering local populations the opportunity to set up "community forests" (Gautier \& Seignobos, 2003). 3) The availability of Landsat images at the same times of the year for these three dates. We chose images acquired at the beginning of the dry season because of their availability and quality. During this period, the differentiation of land-use elements such as crops, herbaceous plants and ligneous plants is maximal (Tabopda, 2009). We downloaded the satellite images from the Earth Explorer (EE) Geospace of the United States Geological Survey (USGS). They were all acquired for the same season of the year in order to reduce problems related to differences in solar angles, soil moisture and phenological changes in vegetation. We used GRASS 7.2.2 (GRASS Development Team, 2017) and QGIS 3.0 (Quantum Geographic Information System Development Team, 2018) for digital image processing and integration of results with other geographic data sources, respectively. The first phase of the treatment consisted of the display of color compositions in false color by superposition of the red and green near-infrared canals for the three dates $(4 \mathrm{R} / 3 \mathrm{~V} / 2 \mathrm{~B}$ for Landsat TM of 1990 and Landsat ETM+ of 1999 , then $5 \mathrm{R} / 3 \mathrm{~V} / 2 \mathrm{~B}$ for Landsat OLI-TIRS of 2016). We limited classification to the park limits and the seven adjoining hunting area that serve as buffer zone around it. A mask was then applied to extract this area of interest. We identified and grouped the similar pixels using a Maximum Likelihood Classifier (MLC) classification. On the basis of the information from the analogue interpretation, our knowledge of the BNNP and its periphery, and field surveys, the twelve classes initially retained were refined after reclassification into eight major classes as shown in Figure 2.

To verify the validity of the performance of the classifications, we used ground-thruthing data collected in the field and the control zones of each class to create a confusion matrix. After validation, we integrated all the relevant spatial information (road network, hydrographic and subdivisional headquaters near the park) into a set of annual land use maps. We performed an evaluation of the areas of the different land cover classes each year and estimated the area of land use changes between 1990 and 1999, and between 1999 and 2016. We quantified vegetation cover dynamics by calculating the overall change rate (Tapobda et al., 2008; Arouna et al., 2009). To estimate the mean annual expansion rate $\mathrm{T}$, we calculated the logarithm ratio of the difference in area between two dates over the number of years of change (Arouna et al., 2009; Taibou et al., 2017).

\subsection{Collection and Analysis of Socio-Economic Data}

We conducted a participatory rural appraisal from august to November 2016, 


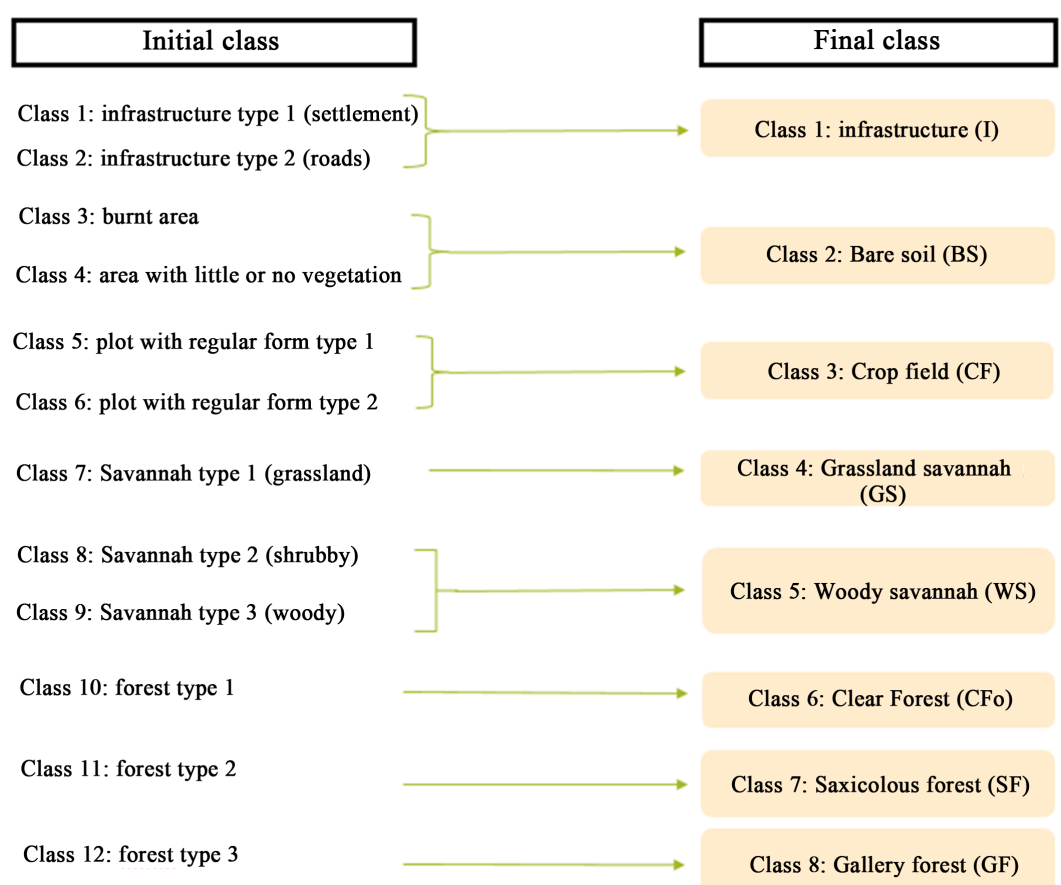

Figure 2. From initial classes to final classes by merging similar themes.

through semi-structured interviews and direct observations to identify the factors affecting the spatio-temporal changes. Out of the 28 villages adjacent to the park, 13 villages selected based on their geographical location (proximity with the park) were sampled. In each village, we realized a focus group to obtain additional information on infrastructure, land use patterns and farming techniques. At the end these focus group, household heads were randomly selected, based on their availability (the period of study coincided with the period of crops harvest) and 126 household heads were surveyed. In each district, the representatives of local administrations (water and forest, agriculture, livestock, territorial administration) and Cotton Development Company were also interviewed. The main information sought during the surveys related to their status (migrant or native), household size, plot size, income-generating activities, exploitation of non-timber forest products and wood forest products in the park, sources of fuel wood supply and their perceptions of the degradation of vegetation cover. Socio-economic data processing was performed by calculating the relative frequencies of each parameter under study. To obtain the data of the population of subdivisions adjoining to the study area in 2016, we made projections based on data from the general census of the population in 2005, considering the average annual rate of population growth of $2.7 \%$ (RGPH, 2010b).

\section{Results}

\subsection{Land Use between 1990, 1999 and 2016 at the BNNP and Its Periphery}

In 1990 the crop fields occupied 2.2\% (15,322 ha) of its area, clear forest $16.3 \%$ 
$(11,088 \mathrm{ha})$, gallery forest $20.2 \%(139,314 \mathrm{ha})$ and woody savannah $42.9 \%$ (295,387 ha) (Table 1). The vegetation cover consisting of the clear forest, gallery forest, saxicolous forest, woody savannah and grassland savannah represented $95 \%(654,370 \mathrm{ha})$ of the surface area of the park and its periphery. Clear forest and gallery forest were found mostly in the southeast and north of the park, while woody savannah covered the park almost entirely (Figure 3(a)). This high recovery rate of vegetation cover denotes the importance of the woody area in 1990. With 4000 ha, the infrastructure accounted for only $0.6 \%$ of the surface area of the BNNP and its periphery. In 1999, crop fields covered 3.6\% (24,455 ha), bare soil $0.8 \%$ (5527 ha) and infrastructure 1.6\% (11,000 ha) of the territory. The vegetation cover occupied $94 \%$ of the BNNP and its periphery (Table 1), mainly distributed in the center and south of the park (Figure 3(b)). In 2016, with 43,714 ha, the crop fields represented $6.3 \%$ of the area of BNNP and its periphery. Crop fields were highly concentrated in the east and in the west of the park, especially around the villages located along roads. The vegetation cover was $82 \%$ ( $566,430 \mathrm{ha}$ ) compared to $1.8 \%$ (12,146 ha) for infrastructure and $9.7 \%(67,122 \mathrm{ha})$ for bare soil (Table 1$)$. Only the central part of the park remained fairly well preserved (Figure $3(\mathrm{c})$ ).

\subsection{Change of the Vegetation Cover and Other Land Use Units between 1990 and 2016}

Between 1990 and 1999, infrastructure, crop field, grassland savannah, woody savannah and the saxicolous forest are the units of land use that have known

Table 1. Land use in the Bouba Ndjidda national park and adjacent areas between 1990 and 2016.

\begin{tabular}{ccccccc}
\hline & \multicolumn{2}{c}{1990} & \multicolumn{2}{c}{1999} & \multicolumn{3}{c}{2016} \\
\cline { 2 - 7 } Classes of land use & $\begin{array}{c}\text { Surface area } \\
(\times 1000 \text { ha })\end{array}$ & $\%$ & $\begin{array}{c}\text { Surface area } \\
(\times 1000 \text { ha })\end{array}$ & $\%$ & $\begin{array}{c}\text { Surface area } \\
(\times 1000 \text { ha })\end{array}$ & $\%$ \\
\hline I & 4.0 & 0.6 & 11.0 & 1.6 & 12.1 & 1.8 \\
BS & 15.7 & 2.3 & 5.6 & 0.8 & 67.1 & 9.7 \\
CF & 15.3 & 2.2 & 24.5 & 3.6 & 43.7 & 6.3 \\
GS & 101.1 & 14.7 & 112.8 & 16.4 & 85.5 & 12.4 \\
WS & 295.4 & 42.9 & 399.7 & 58.0 & 349.9 & 50.8 \\
CFo & 112.1 & 16.3 & 72.4 & 10.5 & 41.1 & 6.0 \\
SF & 6.5 & 0.9 & 14.5 & 2.1 & 10.4 & 1.5 \\
GF & 139.3 & 20.2 & 49.0 & 7.1 & 79.6 & 11.5 \\
Total & 689.4 & 100.0 & 689.4 & 100.0 & 689.4 & 100.0 \\
\hline $\begin{array}{l}\text { Vegetation cover } \\
\text { (GS + WS + CFo }\end{array}$ & 654.4 & 95.0 & 648.5 & 94.0 & 566.4 & 82.1 \\
+ SF + GF $)$ & & & & & & \\
\hline
\end{tabular}

Legend: I: Infrastructure; BS: Bare soils or least vegetated soils; CF: Crop fields; GS: Grassland savannah; WS: Woody savannah; CF: Clear forest; SF: Saxicolous forest; GF: Gallery forest. 


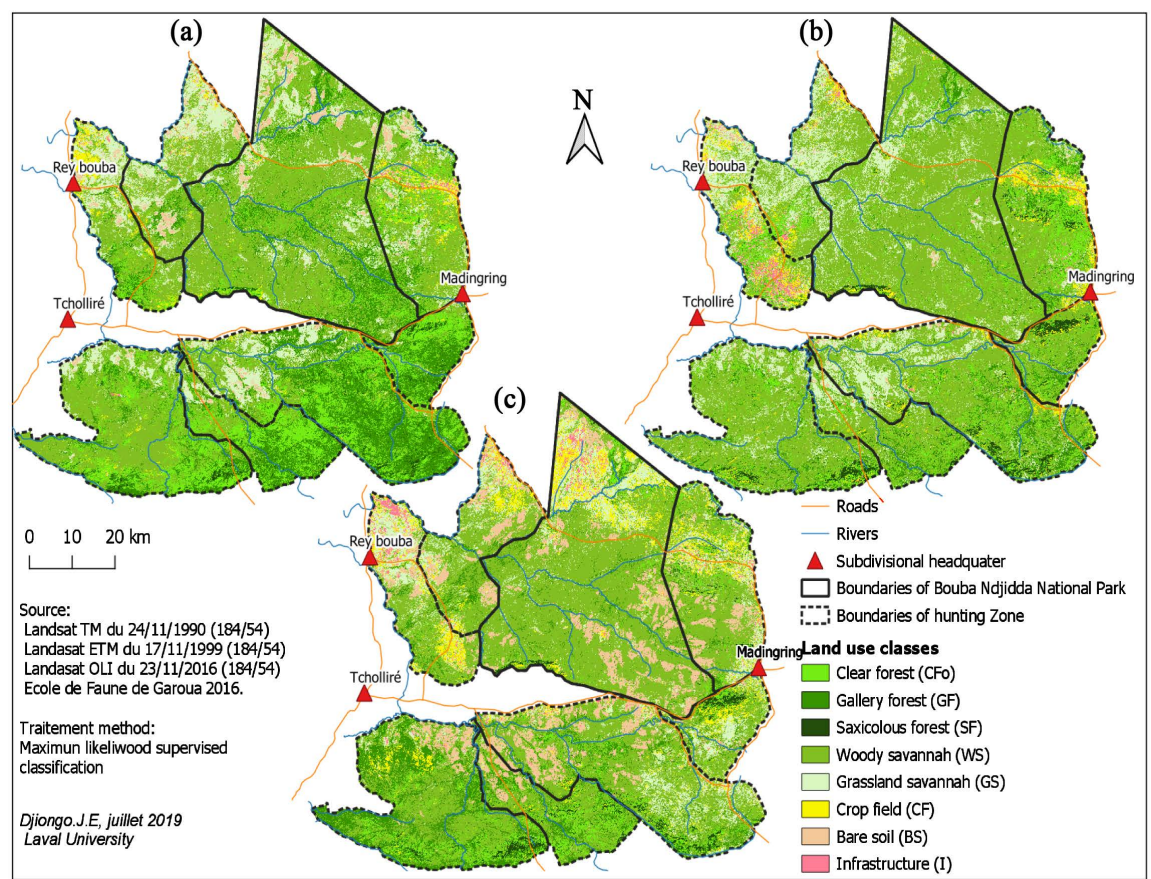

Figure 3. Map of land use in the BNNP and its periphery in (a) 1990; (b) 1999 and (c) 2016.

progressive change. After the saxicolous forest, crop fields experienced the largest increase in area, from 15,322 ha in 1990 to 24,455 ha in 1999 for an overall increase rate of $59.6 \%$. In contrast, the clear forest and gallery forest experienced regressive change with annual growth rates of $-4.9 \%$ and $-11.6 \%$, respectively (Table 2). Between 1999 and 2016, the largest progressive changes were in bare soils and crop fields with average annual growth rates of 14.6\% and $3.4 \%$. In 17 years, the clear forest was the type of vegetation that lost the largest area (31,300 ha) with an overall rate of $-43.2 \%$. Generally, the total vegetation cover decreased by $-82,000$ ha for an annual expansion rate of $-0.8 \%$ (Table 2).

\subsection{Matrix of Land Use Change}

The matrix of land use change presents in a quantified manner all the changes that took place during the different time intervals. The matrices of land use change for the periods of 1990 to 1999 and 1999 to 2016 are shown in Table 3. The diagonals of the matrices represent the surfaces areas of each land use type that remained stable from one period to another.

Between 1990 and 1999, 70.6\% ( 208,443 ha) of woody savannah remained unchanged (Table 3 ). However, the vegetation lost $16 \%$ and $3 \%$ of its surface area in favor of grassland savannah and crop fields, respectively. The most important negative change was that of the clear forest which lost $64.7 \%(\sim 72,470$ ha) of its surface to woody savannah, representing more than half of its surface area, leading to a change in the physiognomy of the landscape. 
Table 2. Changes in land use area in the BNNP and its periphery between 1990 and 1999 and between 1999 and 2016.

\begin{tabular}{ccccccc}
\hline \multirow{2}{*}{$\begin{array}{c}\text { Elements of } \\
\text { land use }\end{array}$} & \multicolumn{2}{c}{ Change between 1990 and 1999} & \multicolumn{2}{c}{ Change between 1999 and 2016} \\
\cline { 2 - 7 } & $\begin{array}{c}\mathrm{C} 1 \\
(\times 1000 \mathrm{ha})\end{array}$ & $\mathrm{Tg}(\%)$ & $\mathrm{T}(\%)$ & $\begin{array}{c}\mathrm{C} 2 \\
(\times 1000 \mathrm{ha})\end{array}$ & $\mathrm{Tg}(\%)$ & $\mathrm{T}(\%)$ \\
\hline I & 7.0 & 177.3 & 11.3 & 1.1 & 10.2 & 0.6 \\
BS & -10.2 & -64.5 & -11.5 & 61.5 & 1101.3 & 14.6 \\
CF & 9.1 & 59.6 & 5.2 & 19.3 & 78.8 & 3.4 \\
GS & 11.7 & 11.6 & 1.2 & -27.3 & -24.2 & -1.6 \\
WS & 104.3 & 35.3 & 3.4 & -49.8 & -12.5 & -0.8 \\
CFo & -39.7 & -35.4 & -4.9 & -31.3 & -43.2 & -3.3 \\
SF & 8.0 & 123.0 & 8.9 & -4.1 & -28.4 & -2.0 \\
GF & -90.3 & -64.8 & -11.6 & 30.6 & 62.3 & 2.8 \\
Vegetation cover & & & & & & \\
(GS + WS + CF & -6.0 & -0.9 & -0.1 & -82.0 & -12.6 & -0.80 \\
+ SF + GF $)$ & & & & & & \\
\hline
\end{tabular}

Legend: I: Infrastructure; BS: Bare soils or least vegetated soils; CF: Crop fields; GS: Grassland savannah; WS: Woody savannah; CF: Clear forest; SF: Saxicolous forest; GF: Gallery forest; S1: Surface area in 1990; S2: Surface area in 1999; S3: Surface area in 2016. C1: Loss or increase in surface area between 1990 and 1999; C2: Loss or increase in surface area between 1999 and 2016. Tg: Total change rate; T: Average annual expansion rate.

Table 3. Matrix of land use change in the BNNP and its periphery from 1990 to 1999 and from 1999 to 2016 (surface area in \%).

\begin{tabular}{ccccccccc}
\hline Land use units & I & BS & CF & GS & WS & CFo & SF & GF \\
\hline $1990-1999$ & & & & & & & & \\
I & 24.5 & 1.4 & 9.1 & 2.0 & 1.7 & 0.8 & 0.1 & 0.4 \\
BS & 5.6 & 1.2 & 2.2 & 3.3 & 0.3 & 0.2 & 0.3 & 0.2 \\
CF & 21.6 & 2.6 & 30.8 & 5.5 & 3.0 & 3.4 & 0.0 & 0.3 \\
GS & 37.4 & 31.5 & 26.7 & 45.7 & 16.0 & 2.4 & 0.8 & 4.4 \\
WS & 9.9 & 57.4 & 22.9 & 39.5 & 70.6 & 64.7 & 3.0 & 47.2 \\
CFo & 0.9 & 4.7 & 7.2 & 3.0 & 6.3 & 18.8 & 7.8 & 19.6 \\
SF & 0.0 & 0.1 & 0.6 & 0.1 & 0.2 & 4.3 & 45.9 & 4.3 \\
GF & 0.2 & 1.3 & 0.5 & 0.9 & 2.1 & 5.4 & 42.1 & 23.6 \\
$1999-2016$ & & & & & & & & \\
I & 14.0 & 24.8 & 8.1 & 3.6 & 0.7 & 0.3 & 0.2 & 0.1 \\
BS & 4.8 & 23.1 & 5.8 & 20.3 & 9.4 & 3.7 & 0.8 & 1.4 \\
CF & 18.7 & 9.9 & 28.6 & 6.1 & 5.8 & 3.8 & 2.7 & 1.7 \\
GS & 23.6 & 21.2 & 33.8 & 25.3 & 9.5 & 5.6 & 1.2 & 5.2 \\
WS & 34.4 & 12.6 & 20.3 & 40.7 & 60.4 & 46.5 & 10.5 & 36.9 \\
CFo & 1.1 & 0.8 & 1.1 & 0.5 & 4.5 & 16.0 & 23.3 & 14.5 \\
SF & 0.1 & 0.3 & 0.9 & 0.0 & 0.4 & 2.2 & 44.3 & 1.1 \\
GF & 3.3 & 7.5 & 1.5 & 3.5 & 9.3 & 21.9 & 17.2 & 39.1 \\
\hline
\end{tabular}

Legend: I: Infrastructure; BS: Bare soils or least vegetated soils; CF: Crop fields; GS: Grassland savannah; WS: Woody savannah; CF: Clear forest; SF: Saxicolous forest; GF: Gallery forest. 
Between 1999 and 2016, the highest conversion was still that of the clear forest, which lost 3.8\% (2743 ha), 5.6\% (4065 ha), 21.9\% (15,875 ha) and 46.5\% $(33,675 \mathrm{ha})$ of its surface area respectively to crop fields, grassland savannah, gallery forest and to the woody savannah. At the same time, a considerable decline in woody savannah was observed in favor of the crop fields, with a loss of $5.8 \%(23,229 \mathrm{ha})$. The same trend was obtained for grassland savannah, which lost $20.3 \%$ and $6.1 \%$ of its surface area to bare soils and crop fields, respectively. Generally, between 1990 and 2016, the vegetation cover conversions amounted to $18.8 \%$ in favor of the anthropized area represented by crop fields, bare soils and buildings.

\subsection{Local Perception Factors of Degradation of the BNNP and Its Periphery}

The neighboring populations cited several factors responsible for the degradation of the vegetation cover in the BNNP and its periphery (Figure 4).

Demographic factors were the main causes of degradation of the vegetation cover in the BNNP and its periphery as reported by $92.5 \%$ of the respondents. In fact, between 1987 and 2016, the population of the three subdivisions (Madingring, Tcholiré and Rey Bouba) that adjoin the park increased considerably (Figure 5). In 29 years, this population almost quintupled in the Rey Bouba Subdivision where it rose from 10,000 inhabitants in 1987 to approximately 146,700 inhabitants in 2016 (RGPH, 1987; RGPH, 2005; RGPH, 2010b). According to data from the third census of the population of Cameroon, a household is composed of an average of 5 persons, with more than $15 \%$ of rural households being composed of at least 9 persons. The latter situation reflects the size of households in the Mayo Rey Division. The migrations

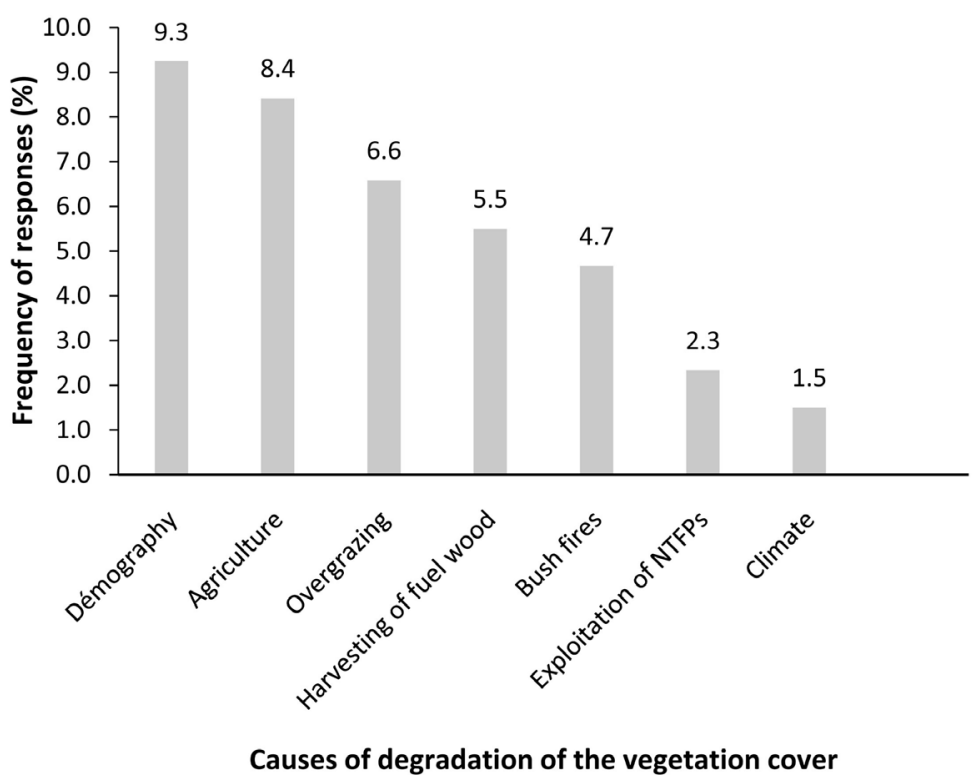

Figure 4. Frequency of citation of causes of degradation of the vegetation cover by populations neighboring to the BNNP. 


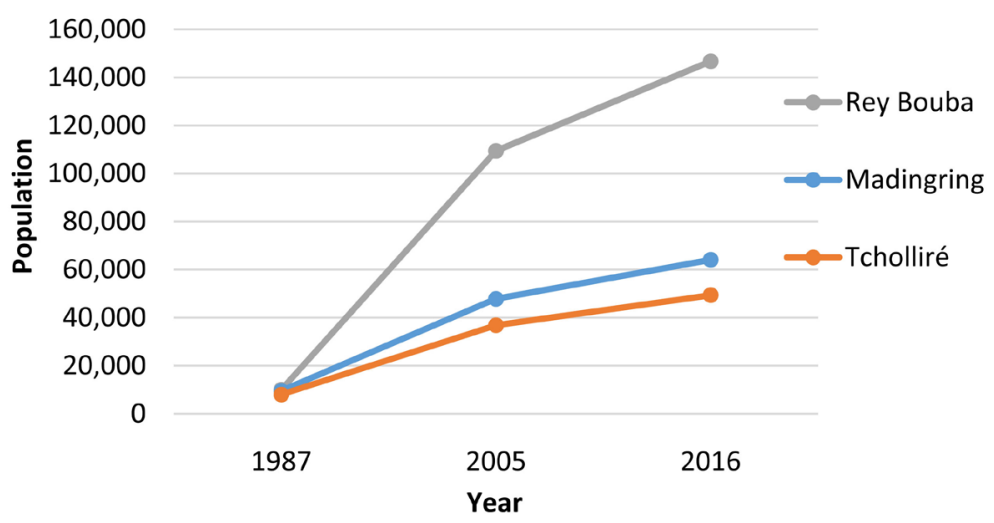

Figure 5. Change in human population of the Subdivisions surrounding BNNP between 1987 and 2016 (RGPH, 1987; RGPH, 2005; RGPH, 2010b)/Projection 2016.

organized by the administration since the year 1972 with the aim of decreasing population densities in the Far North and spontaneous migrations in the Benoue basin (North Cameroon) favored this strong demographic growth. According to Dugué et al. (1994) cited by Mfewou (2013), the extent of migrant installations after the years 1970s in the Benoue basin corresponds to a territory of about 20 inhabitants $/ \mathrm{km}^{2}$ with an annual growth rate of $3.14 \%$. In our study, $40 \%$ of those surveyed were migrants.

Agriculture: Out of the $84.2 \%$ of the neighboring populations surveyed, agriculture was the second cause of degradation of the vegetation cover in the BNNP and its periphery. The BNNP occupies $76.74 \%$ of the population of the Bouba Ndjidda TOU (WWF, 2007). It is mainly dominated in order of importance by food crops (maize, groundnuts, cow pea, millet/sorghum, cassava, yam), which constitute the staple foods for the majority of the population and cash crop cultivation (with cotton being the only cash crop in the Division). Cultivated land for the different crops in the Mayo Rey Division is increasing. The areas of the plots exploited per household varied from 1 to more than 20 ha according to the objectives, the financial means and the agricultural equipment owned by farmers. However, $84.13 \%$ of the respondents had plans to increase their arable plots by more than 2 ha (14.29\%) and by 1 ha (1.50\%). The extension of cultivation space of a specific crop is also linked to its profitability during the previous agricultural season. For example, if during the year during which the price of a bag of $50 \mathrm{~kg}$ of maize can vary from 12,000 FCFA to 20,000 FCFA, the farmer will tend to increase the areas reserved for maize cultivation without necessarily reducing that of other crops, in order to maximize profit the following year. Farmers initiate new agricultural plots after the total or partial destruction of natural vegetation cover.

Livestock rearing is the second economic activity after agriculture in the study area. It is practiced extensively by sedentary and transhumant shepherds. Sixty-five percent $(65.8 \%)$ of the respondents indicated that overgrazing was responsible for the degradation of the vegetation cover through the setting up of the camps and the pruning of the trees. In the dry season, transhumant pastoral- 
ists entered and settled inside the Protected Areas. During their displacement, they routinely prune fodder species (Afzelia africana, Ficus sp., Acacia sp. and Balanites eagyptiaca) to feed livestock, and the bark of certain trees such as Lannea kerstingii, Andansonia digitata that serves as bedding. This high pastoral pressure is explained by the fact that the settling of migrants in the area has led to the occupation of the pastoral grazing areas of pastoralists, forcing them to look for the new territories which were found in the parks and the adjoining hunting areas. Pressure from herders was high in the northern part of the park due to the presence of the Vaimba river, which does not dry completely in the dry season and which therefore attracted Mbororo breeders from Chad. The herders' pressure was low inside the park, due to increased surveillance around the office of conservation service and the tourist camp. However, in the hunting zone 23 abandoned in recent years, the shepherds had taken up residence.

Harvesting of fuel wood (firewood and charcoal production) is one of the most harmful practices for the natural regeneration of vegetation cover in Protected Areas. This harvesting, which is manifested by anarchic cuttings, were frequent inside the BNNP and the surrounding hunting zones. According to local officials of the Ministry of Forests and Wildlife (MINFOF), the illegal cutting of woody species is the most reported offense after wildlife poaching. The populations adjacent to the BNNP non-selectively use a variety of woody species as firewood while for charcoal production, they are selective and use in order of importance Daniella oliveri (42.11\%), Annogeissus leocarpus (38.6\%), Prosopis africana (15.7\%), Ficus capensis (1.7\%), Zizuphus mauritiana (1.7\%). Per capita consumption of firewood around BNNP is estimated at $1.17 \mathrm{~kg} / \mathrm{day}$ and that of coal at $3.45 \mathrm{~kg} / \mathrm{inhabitant/day} \mathrm{(field} \mathrm{surveys).} \mathrm{Some} \mathrm{officials} \mathrm{of} \mathrm{MINFOF} \mathrm{issue}$ wood traders Authorizations for the Collection and Transport of Deadwood (ACTBM) subject to payment of 500 FCFA for a carrier whose quantity is equivalent to a stere wood. The Divisional Delegate of Forests and Wildlife for Mayo Rey Division has signed a note within the framework of the usufruct rights of local populations, authorizing free access to dead wood for domestic use. Inspite of this provision, neither the collection sites, the quantities granted nor the quality (fresh wood forbidden fresh) are not always respected.

Bush fires, mainly of human origin, were used by farmers at the periphery of the park to clean their farms (slash-and-burn agriculture). Inside the park, they were used either for hunting by poachers or for the renewal of grazing by BNNP managers and transhumant pastoralists who enter the park illegally. The effects of bush fires on plant resources result in an increase in soil temperature, the destruction of surface organic material, and in turn, to a decrease in the productivity of the vegetation.

The exploitation of non-timber forest products (NTFPs) was reported by $23.3 \%$ of respondents to be one of the causes of degradation of vegetation cover. The BNNP and its periphery constitute for the local populations an important reserve of products for the traditional pharmacopoeia, the construction of huts and food. There, they collect backs of trees (Daniella oliveri, Detarium micro- 
carpum, Anogeissus leocarpus, etc.), straw (Jardinea congoensis and Hyparrhenia rufa), fruits and leaves of trees (Tamarindus indica, Brideliasp., etc.), and honey. This exploitation of NTFPs is usually anarchic and uncontrolled. The exploitation of NTFPs and wood forest products inside the park is prohibited and regulated in adjacent ZICs. The use of unsustainable harvesting techniques by farmers could lead to a decrease or even to the extinction of some plant species.

Climatic factors (rainfall): Between 1990 and 2016, the rainfall of the Bouba Ndjidda TOU exhibited a downward trend (Figure 6). Depending on whether the recorded rainfalls are in excess or in deficit, they affect land use differently, mainly on the extension of agricultural spaces. The dates marking the start of rainy seasons determined farming practices.

During the last 26 years, low rainfall was recorded in 1992 and 2011. This, with other factors could explain the increases in cultivated lands the following years.

\section{Discussion}

\subsection{Land Classes and Image Processing}

We identified eight classes of land cover, five linked to natural vegetation (clear forest, saxicolous forest, gallery forest, woody savannah and grassland savannah) and three linked to anthropogenic activities (bare soil, crop fields and infrastructure). Vegetation surveys carried out by Bosch (1976) and Nature Information Tracks (2017) in the BNNP showed that the plant formations are made of six classes including clear forest, gallery forest, saxicolous forest, shrubby savannah, woody savannah and grassland savannah. As part of this study, for a better cartographic representation, we reclassified the type 1 savannah (shrubby) as woody savannah. Apart from the anthropic land uses, the mapping results confirmed the physionomic descriptions done by Bosch (1976) and Nature Information Tracks (2017).

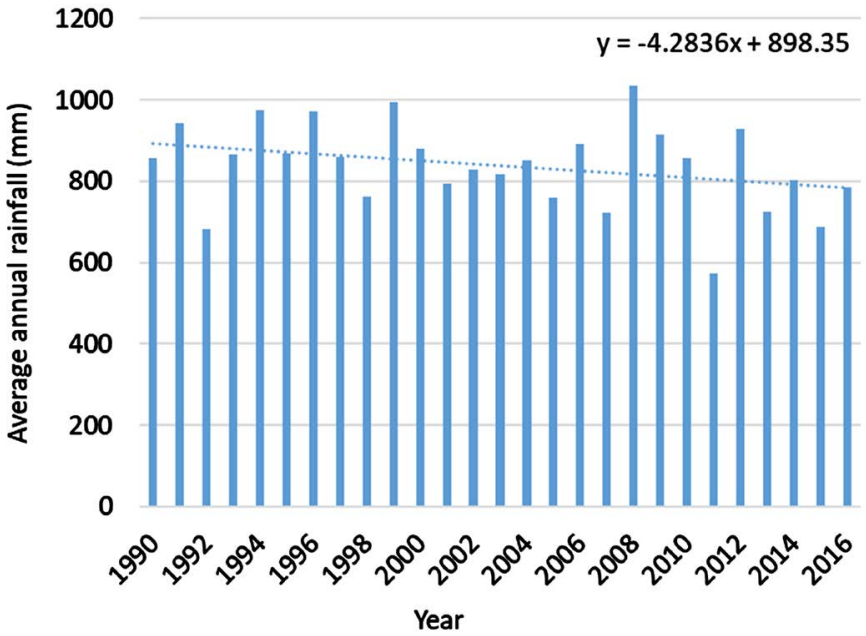

Figure 6. Interannual variation in meanrainfall of the study area from 1990 to 2016. Source: Garoua Weather Station, 2017. 
Regarding the method for mapping land use, the strong influence of vegetation on the spectral signatures made it difficult to differentiate between the plant formations (clear forest, woody savannah, grassland savannah and crop fields). We ascribe the confusion between the grassland savannah and crop fields to the fact that the useful trees left in the fields give to this class the appearance of a grassland in some places; the same is true for fallows classified as crop fields due to the difficulty in differentiating them from the grassland savannah. The spectral confusion between water and bare soil created by bush fire also made the classification difficult. In this case, ground-thruthing helped us to assign homogeneous pixels well known and accurate to different classes. In spite of these difficulties, the image treatment process as well as the mapping results remain satisfactory, since the kappa indices obtained were $76.5 \%, 73.6 \%$ and $72.03 \%$, for mages of 1990, 1999 and 2016, respectively. The quality of images and the choice of thematic classes could explain such results (Geymen \& Baz, 2008). For all three dates, the overall classification rate was greater than $70 \%$, which permits the validation of the maps (Kabba \& Li, 2011; Pontius, 2000).

\subsection{Dynamics of Vegetation Cover and Explanatory Factors}

The spatio-temporal analysis of land use in the BNNP and its periphery showed a redecline of natural plant formations of $13.4 \%$ (clear forest, gallery forest, saxicolous forest, woody savannah and grassland savannah) in 26 years at the expense of anthropogenic cover, namely crop fields, bare soil, and infrastructure, the surface area of which increased fourfold. The clear forest particularly recorded a decrease of more than $50 \%$ of its surface. These results are similar to those of Temgoua et al. (2018b) in the classified forest of Djio-li-Kera in southeast Chad and those of Benoudjita \& Ignassou (2017) in and around the W Regional Park of Benin, which showed a continuous regression in forest and savannah at the expense of fallows, crop fields, bare soil and settlements. The search for new arable land to feed a population in perpetual growth could justify the increase over the years of anthropogenic spaces. Indeed, the average growth rate of the population in the study area is $3.9 \%$, far above the national rate of $2.8 \%$ (RGPH, 2010a). Following this demography and the migrants recorded in the region since the 1970s, many plots were installed in the park during the last two decades. In addition, the network of Protected Areas of North Cameroon occupied $44 \%$ of the total surface area of the region; BNNP and its adjacent zone occupying about $50 \%$ of Mayo Rey Division (Ministry of Forest and Wildlife, 2010a). These Protected Areas benefited from a more or less strict protection status depriving neighboring populations of arable surfaces, which forced them to extend agricultural lands towards the Protected Areas. Demography is one of the main causes of degradation of BNNP and its periphery. It significantly influences land use through the size of household farm assets (Houessou et al., 2013). In fact, the needs of a family vary according to the number of constitutive members; thus, the larger it is, the greater the need. In response to increasing household demands farmers often decide to clear new fields to overcome family 
burdens. This corroborates the results of Ouedraogo et al. (2010) who concluded at the end of their work that there is a strong correlation between population growth and land degradation. We explain the influence of agriculture on land degradation by the presence of the Cotton Development Corporation (SODECOTON) in the region. Indeed, the cotton sector is supported by the state with subsidies via the provision of diverse inputs (fertilizer), varied supervision (farmers' supervision), and available market for the cotton produced (purchase of all production). The quantity of inputs provided free of charge or on credit depends on the size of the cotton field. Subsidies acquired by the farmer probably contribute to the increase in the area of cotton fields. To further optimize the use of fertilizers in cotton fields, farmers juxtapose cornfields and cotton fields (depending on the direction of runoff and the location of cotton field upstream) or rotate crops by growing maize on former cotton fields that sometimes benefit from new wasteland. Generally, there is net expansion of cotton cultivation in the study area (Bokagne, 2006) with SODECOTON opting for the opening of extension service centres to facilitate farmers' increase of cotton production through the occupation new wasteland, and to facilitate the transport and recovery of cotton produced. From an overgrazing point of view, tree pruning and livestock grazing by transhumant pastoralists are the main threats to BNNP's plant resources; the pressure being higher on the species Afzelia africana, which is systematically pruned to feed livestock. Hountondji (2008) also described the harmful effects of transhumant livestock farming on the degradation of vegetation cover in the Sahelian and Sudanian zones of West Africa. In addition to the pressure on specific plant species, the regular passage of recent bush fires does not favor the recovery of natural vegetation and thus contributes to increasing bare soil surfaces (Lubalega et al., 2018). The exploitation of NTFPs is a usufruct right of riparian populations of Protected Areas in tropical countries. However, the understanding of this notion remains subject to conflicting and divergent interpretations. Although poaching was not cited by farmers as a cause of vegetation cover degradation, it indirectly affects woody resources. The same observation was made by the UICN (2014) in the study on the drivers of deforestation and degradation in the Sangha Tri-National (TNS) landscape. Poachers use wood for camp construction, game conservation and heating. The effects of climate on the vegetation cover could be explained by the fact that when rainfall corresponds to the expectations of the producers, the cultivated lands are not systematically increased between two cropping seasons. But when the rainfall is below average, there is a compensatory increase of farming area.

Several scientific studies in Cameroon and elsewhere have attempted to document and explain land use change. Tabopda (2009) documented deforestation through the harvesting of fuel wood in the Protected Areas of the Far North of Cameroon and Temgoua et al. (2018a) reported agricultural extension and grazing as factors leading to the degradation of the Ajei community forest in the North West region of Cameroon. In Burkina Faso, Tankoano et al. (2016) identified agriculture, timber harvesting and extension of residential areas as the 
main drivers of degradation in the Deux Balé National Park. Other studies at the global level have categorized factors related to land cover and land use change. Fotsing (2009) classified them into two broad categories, namely: human factors that include socio-economic and political factors; and biophysical factors. All these factors constitute a complex network of interactions between them making it possible to understand the dynamics of land cover or specific land use in space. For Lambin et al. (2007) cited by Boko (2012), there are six categories of direct or indirect factors contributing to the dynamics of land cover and land use change; namely demographic, economic and technological, cultural, globalization, institutional and natural variability. Apart from globalization, there is no difference between the factors cited by Fotsing et al. (2013) and Lambin et al. (2007) and those of this study. However, in their review, Lambin et al. (2003) conclude that changes in land use are due to a combination of causes that can also act as constraints in forcing actors to make decisions about degradation, innovation or displacement.

According to Boserup (2002), population growth can lead to land degradation in the short term, but can also stimulate innovation, especially the adoption and intensification of eco-farming and conservation techniques as agroforestry which is known as any simultaneous or sequential association of trees, crops and/or animals in the same production unit (Atangana et al., 2014). The use of agroforestry systems on the buffer zone of protected area can offer a variety of products and services that meet some of the needs of local populations. These benefits therefore allow them to avoid using the protected natural area to support themselves. In this context, considering the growing needs of riparian communities for arable land, pastures, fuelwood and NTFPs, the practice of agroforestry should be intensified. We also recommend strengthening surveillance of the park, especially in the northern zone, which is subject to high livestock rearing pressures.

\section{Conclusion}

The main aim of this research was to analyze and quantitatively assess the spatio-temporal changes in vegetation cover in the Bouba Ndjidda National Park and its surrounding area between 1990 and 2016. The vegetation cover has declined by approximately $13.44 \%$ in 26 years, representing a loss of approximately 87,940 ha for fields, bare soil and human infrastructure. The corresponding increase of anthropogenic land use has as a corollary a change of facies and physiognomy in this Protected Area. The combined effects of demographic, socio-economic and climatic factors could explain the observed changes. To be consistent with the current paradigm of participatory management, we recommend the development of income-generating agro-sylvopastoral activities. This involves improving the agricultural and pastoral production systems in line with population growth. A macro zoning that takes into account a multipurpose use of the zone is also recommended. 


\section{Conflicts of Interest}

The authors declare no conflicts of interest regarding the publication of this paper.

\section{References}

Arouna, O., Toko, I. I., Djogbenou, C. P., \& Sinsin, B. (2009). Dynamique et caractéristiques phytoécologique des formations végétales résiduelles dans la Commune de Djidja au Bénin. Actes du 2eme Colloque de I'UAC des Sciences, Cultures et Technologies, Sciences Agronomiques (pp. 406-421).

Atangana, A., Khasa, D., Chang, S., \& Degrande, A. (2014). Definitions and Classification of Agroforestry Systems. In Tropical Agroforestry (pp. 35-47). Dordrecht: Springer. https://doi.org/10.1007/978-94-007-7723-1_3

Benoudjita, N., \& Ignassou, A. D. (2017). Comment les aires protégées structurent les écosystèmes des périphéries. International Journal of Biological Chemical Sciences, 11, 2225-2242. https://doi.org/10.4314/ijbcs.v11i5.22

Scholte, P. (2012). Le parc national de Bouba-Ndjida. In Aires protégées d'Afrique Centrale. État 2015, Kinshasa, République Démocratique du Congo et Yaoundé, Cameroun: Observatoire des forêts d'Afrique centrale (OFAC). p. 53.

Bokagne, B. F. (2006). Evolution et situation actuelle de l'agriculture et de l'élevage. 24 Yaoundé.

Boko, G. J. (2012). Trajectoires des changements dans l'occupation du sol: déterminants et simulation. Cas du bassin versant de l'Alibori (291 p.). Benin, Afrique de l'Ouest: EDP/FLASH/UAC.

Bosch, M. (1976). Enquête écologique du Parc National de Bouba Ndjida. Rome: FAO.

Boserup, E. (2002). Technological Society and Its Relation to Global Environmental Change. In Encyclopedia of Global Environmental Change, Social (pp. 86-96).

Brabant, P. (1972). Notice Explicative de la carte pédologique de reconnaissance à 1/200.000: feuille Rey-Bouba.

Djiongo, B. J. E. (2015). Contribution de l'agroforesterie à la réduction des conflits dans la zone d'intérêt cynégétique 19 de Tchéboa, Cameroun (95р.). Canada: Université Laval.

Doumenge, C., Palla, F., Scholte, P., Hiol Hiol, F., \& Larzillière, A. (2015). Aires protégées d'Afrique centrale-État 2015 (256 p.). Cameroun: OFAC, Kinshasa, République Démocratique du Congo et Yaoundé.

Dudley, N. (2008). Guidelines for Applying Protected Area Management Categories. Gland, Suisse: IUCN. https://doi.org/10.2305/iucn.CH.2008.PAPS.2.en

Dugué, P., Koulandi, J., \& Moussa, C. (1994). Diversité et zonage des situations agricoles et pastorales de la région cotonnière du Nord-Cameroun. CIRAD-CA.

Fotsing, E. (2009). SMALL Savannah: Un système d'information pour l'analyse intégrée des changements d'utilisation de l'espace à l'extrême nord du Cameroun. Pays-Bas: Universiteit Leiden.

Fotsing, E., Verburg, P. H., \& De Groot, W. T. (2013). Cheylan Jean-Paul et Tchuenté Maurice, 2013. Un modèle intégré pour explorer les trajectoires d'utilisation de l'espace. ARIMA Journal, 16, 1-28.

Gautier, D., \& Seignobos, C. (2003). Histoire des actions de foresterie dans les projets de développement rural au Nord-Cameroun. In Savanes africaines: des espaces en mutation, des acteurs face à de nouveaux défis. Actes du colloque, Garoua, Cameroun.

Geymen, A., \& Baz, I. (2008). The Potential of Remote Sensing for Monitoring Land 
Cover Changes and Effects on Physical Geography in the Area of Kayisdagi Mountain and Its Surroundings (Istanbul). Environmental Monitoring Assessment, 140, 33-42. https://doi.org/10.1007/s10661-007-9844-6

Gonné, B. (2016). Climat et ruralité en zones soudaniennes et sahéliennes du Cameroun et du Tchad. Editions L'Harmattan.

Goudet, J. P. (1992). La foresterie. In P. M. Bosc, P. Garin, J. M. Yung (EdS.), Le développement agricole au Sahel, Vol. Tome II: Recherches et techniques (pp. 113-126). Montpellier: CIRAD. Coll. Documents Systèmes Agraires 17.

GRASS Development Team (2017). Geographic Resources Analysis Support System (GRASS) Software, Version 7.2.2. Open Source Geospatial Foundation. https://grass.osgeo.org

Houessou, L. G., Teka, O., Imorou, I. T., Lykke, A. M., \& Sinsin, B. (2013). Land Use and Land-Cover Change at "W" Biosphere Reserve and Its Surroundings Areas in Benin Republic (West Africa). Environment Natural Resources Research, 3, 87. https://doi.org/10.5539/enrr.v3n2p87

Hountondji, Y. C. H. (2008). Dynamique Environnementale en zones sahélienne et soudanienne de l'Afrique de l'Ouest: Analyse des modifications et évaluation de la dégradation du couvert végétal. Belgique: Université de Liège.

Kabba, V. T. S., \& Li, J. (2011). Analysis of Land Use and Land Cover Changes, and Their Ecological Implications in Wuhan, China. Journal of Geography and Geology, 3, 104. https://doi.org/10.5539/jgg.v3n1p104

Lambin, E. F., Geist, H. J., \& Lepers, E. (2003). Dynamics of Land-Use and Land-Cover Change in Tropical Regions. Annual Review of Environment, 28, 205-241. https://doi.org/10.1146/annurev.energy.28.050302.105459

Lambin, E., Geist, H., \& Ellis, E. (2007). Causes of Land-Use and Land-Cover Change. In C. J. Cleveland (Ed.), Ecncyclopedia of Earth. Washington DC Environmental Information Coalition, National Council for Science and Environment. http://editors.eol.org/eoearth/wiki/Causes_of_land-use_and_land-cover_change

Lubalega, T., Lubini, C., Ruel, J., Khasa, D., Ndembo, J., \& Lejoly, J. (2018). Structure et composition floristique de savanes arbustives en système préservé du feu à Ibi, plateau des Bateke, en République Démocratique du Congo. Revue Scientifique et Technique Forêt et Environnement du Bassin du Congo-RIFFEAC, 9, 20-30.

Mfewou, A. (2013). Migrations, dynamiques agricoles et problèmes fonciers en Afrique subsaharienne: Le périmètre irrigué de Lagdo (Nord-Cameroun). Cybergeo: European Journal of Geography.

Ministry of Forest and Wildlife (2010a). Development Plan for Bouba Ndjidda National Park and Its Peripheral Area (2010-2014). 107.

Ministry of Forest and Wildlife (2010b). Impact Monitoring of the Sectoral Forest Environment Programme (PSFE): Evolution of the Permanent Forest Domain Area and Evolution of the Forest Area. Yaounde.

Montagne, P., \& Dubus, P. (1992). Nouvelle Foresterie-Centre-Est Sénégal, In P. M. Bosc, V. Dollé, P. Garin, \& J. M. Yung (Eds.), Le développement agricole au Sahel Vol. Tome III: Terrains et innovations (pp. 281-296). Montpellier: CIRAD. Coll. Documents Systèmes Agraires 17.

Nature Information Tracks (2017). E tat des lieux sur les formations végétales dans le parc national de Bouba Ndjidda et sa zone périphérique (77 p.).

Omondi, P., Bitok, E. K., Tchamba, M., Mayienda, R., \& Bene Bene, L. (2008). Total Aerial Count of Elephants and Other Wildlife Species in Faro, Benoue and Bouba Ndjidda National Parks and Adjacent Hunting Blocks in Northern (75 p.). Cameroun: 
WWF-Ministry of Forest and Wildlife.

Ouedraogo, I., Tigabu, M., Savadogo, P., Compaoré, H., Odén, P. C., \& Ouadba, J. M. (2010). Land Cover Change and Its Relation with Population Dynamics in Burkina Faso, West Africa. Land Degradation \& Development, 21, 453-462. https://doi.org/10.1002/ldr.981

Pontius, R. G. (2000). Quantification Error versus Location Error in Comparison of Categorical Maps. Photogrammetric Engineering and Remote Sensing, 66, 1011-1016.

Quantum Geographic Information System Development Team (2018). QGIS Geographic Information System. Open Source Geospatial Foundation Project. http://qgis.osgeo.org

RGPH (1987). Deuxième Recensement Général de la Population et de l'habitat du Cameroun (Vol. 3, 83 p.). Analyse préliminaire. Yaoundé: Bureau Central des Recensements et des Etudes de la Population.

RGPH (2005). 3eme Recensement Général de la Population Humaine. Rapport de présentation des résultats définitifs (67 p.). Yaoundé: Bureau Central des Recensements et des Etudes de la Population.

RGPH (2010a). Troisième Recensement Général de la Population et de l'habitat du Cameroun. Analyse Thématique. Caractéristiques sociodémographiques des ménages ordinaires (Vol. II). Yaoundé: Bureau Central des Recensements et des Etudes de la Population.

RGPH (2010b). Troisième Recensement Général de la Population et de l'habitat du Cameroun. Projections démographiques (Vol. III, 91 p.). Yaoundé: Bureau Central des Recensements et des Etudes de la Population.

Tabopda, G. W. (2009). Les aires protégées de l'Extrême-Nord Cameroun entre politiques de conservation et pratiques locales. L'information géographique, 73, 62-68.

https://doi.org/10.3917/lig.734.0062

Taibou, B., Akpo, L. E., \& Diouf, A. A. (2017). Dynamique spatio-temporelle des écosystèmes du bassin versant du Ferlo (Nord-Sénégal). Journal of Animal Plant Sciences, 33, 5255-5273.

Tankoano, B., Hien, M., Dibi, N., Sanon, Z., Akpa, Y., Sokeng, V. J., Somda, I. J. I. J. O. I., \& Studies, A. (2016). Cartographie de la dynamique du couvert végétal du Parc National des Deux Balé à l'Ouest du Burkina Faso [Mapping Land Cover Dynamics of Deux Balé National Park, Western Burkina Faso]. International Journal of Innovation and Applied Studies, 16, 837.

Tapobda, W. G., Kenji, O., \& Fotsing, J. M. (2008). Analyse spatio-temporelle de l'occupation du sol dans le Parc National de Waza entre 1986 et 2001 (Nord Cameroun). Revue française de photogrammétrie et de télédétection, No. 189, 40-50.

Tardif, J., \& Sarrasin, B. (2014). La territorialisation par et pour l'écotourisme dans les aires protégées (pp. 354-359). CIST2014-Fronts et frontières des sciences du territoire.

Temgoua, L. F., Ajonina, G., \& Woyu, H. B. (2018a). Land Use and Land Cover Change Analysis in Ajei Upland Watershed Community Forest, North West Region, Cameroon. Journal of Geoscience Environment Protection, 6, 83. https://doi.org/10.4236/gep.2018.69007

Temgoua, L. F., Allaissem, B., Tchamba, M., Saradoum, G., Osée, M. M., \& Solefack, M. C. M. (2018b). Spatio-Temporal Dynamic of Land Use and Land Cover in the Classified Forest of Djoli-Kera, South-Eastern, Chad. Open Journal of Forestry, 8, 283-296. https://doi.org/10.4236/ojf.2018.83019

UICN (2014). Les Facteurs de Déforestation et de Dégradation des Forêts: Résultats d'une analyse participative dans les Paysages TNS et TRIDOM (81 p.). Cameroun, Congo: 
Gabon et RCA.

World Wide Fund for Nature (WWF) (2007). Etude socio-économique de l'UTO de Bouba Ndjida. Réalisée par le Groupe d'Initiave Economique (GIE) Territoire et Développement (TERDEL) (196 p.). Garoua: WWF. 